\title{
Rafal Matyja*
}

\section{ZACHOWANIA WYBORCZE MIESZKAŃCÓW MIAST W LATACH 1990-2015 A AFILIACJE POLITYCZNE ICH PREZYDENTÓW PO 2002 ROKU}

Największym zaskoczeniem pierwszych bezpośrednich wyborów prezydentów miast było to, że w miastach uznawanych potocznie za prawicowe (to znaczy takie, w których prawica miała przewagę w wyborach parlamentarnych i którymi rządziły centroprawicowe większości w radzie) zwyciężyli kandydaci SLD-UP. Najbardziej spektakularne sukcesy odnieśli wówczas Jacek Majchrowski w Krakowie i nowo wybrany poseł SLD - Tadeusz Ferenc w Rzeszowie. Obaj utrzymali władzę przez następne lata i w wyborach 2014 roku zdecydowanie wygrali kolejną rywalizację o fotel prezydenta. O ile w roku 2002 można było ich zwycięstwo tłumaczyć wysoką popularnością SLD, które rok wcześniej wygrało wybory parlamentarne, o tyle powtórzenie tego sukcesu w ciężkim dla lewicy roku 2006 wykazywało, że to nie partyjny szyld dał zwycięstwo Majchrowskiemu i Ferencowi.

Warto dodać, że zwycięstwo SLD w „bastionach prawicy” nie było jedyną niespodzianką tych wyborów. W liberalnie nastawionej Warszawie prezydentem został Lech Kaczyński z PiS i to mimo tego, że nie udało się zawrzeć koalicji z PO, a jego konkurentem w pierwszej turze był niedawny kandydat na prezydenta RP Andrzej Olechowski, który mimo świetnego wyniku osiągniętego dwa lata wcześniej, nie zdołał zakwalifikować się do drugiej tury. To zapewne otworzyło Kaczyńskiemu drogę do zwycięstwa, bo w drugiej turze elektorat centrowy i liberalny musiał wybierać między kandydatem PiS a kandydującym z poparciem

\footnotetext{
dr hab. Rafał Matyja, Wyższa Szkoła Informatyki i Zarządzania w Rzeszowie, e-mail: rmatyja@wsiz.rzeszow.pl
} 
SLD-UP Markiem Balickim. Warto zapamiętać ten przypadek, bo bardzo często o wyborze prezydenta przesądza nie wynik pierwszej, a konfiguracja drugiej tury.

Kandydaci centroprawicowi wygrywali także w takich miastach, w których wybory sejmowe wyraźnie wygrywała lewica. Zwycięstwo centroprawicowego kandydata zdarzyło się nawet tam, gdzie rok wcześniej listy SLD-UP zdobywały bezwzględną większość głosów w wyborach sejmowych. Tak było m.in. w Łodzi, gdzie wygrał Jerzy Kropiwnicki, wyrazisty polityk ZChN, minister w rządzie Jerzego Buzka; w Kielcach, gdzie prezydentem został związany z AWS były wojewoda Wojciech Lubawski, a także w Zielonej Górze i Wałbrzychu. Również w wielu mniejszych miastach prezydenckich (m.in. Lubinie, Nowym Sączu) wyniki były odwrotne do przewidywanych na podstawie poprzednich wyborów parlamentarnych i prezydenckich.

Czy taki stan rzeczy, jaki obserwowaliśmy w 2002 roku utrzymał się, czy też w większości miast sprawy „wróciły do normy” i prezydentami miast zostawali później kandydaci najsilniejszych w mieście ugrupowań? Czy istnieją dające się uchwycić reguły, mówiące o tym, w jakich sytuacjach może dojść w mieście do wyboru prezydenta z odmiennej orientacji politycznej niż ta, która dominuje w wyborach sejmowych? Pytania te stały się przyczynkiem badań zaprezentowanych w artykule.

\section{Przesłanki badania}

Po 25 latach, jakie upłynęły od pierwszych demokratycznych wyborów, w których Polacy w sposób wolny i nieskrępowany wybrali rady gmin, można z powodzeniem mówić o tym, że liczba danych dotyczących zachowań wyborczych jest dostatecznie duża, by w ich modelowaniu wyjść poza proste wzorce. W prowadzonych w latach 90 . XX wieku badaniach zwracano bowiem przede wszystkim uwagę na aspekty związane z oceną wydarzeń historycznych (podział postkomunistyczny) ${ }^{1}$, przekonań i praktyk religijnych (oś klerykalizmlaicyzm)², czynników tradycji i długiego trwania (przede wszystkim podziałów

1 M. Grabowska, Podziat postkomunistyczny. Społeczne podstawy polityki w Polsce po 1989 roku, Warszawa 2004.

2 K. Jasiewicz, Portfel czy różaniec? Ekonomiczne i aksjologiczne determinanty zachowań wyborczych, w: Wybory parlamentarne 1997. System partyjny, postawy polityczne, zachowania wyborcze, red. R. Markowski, Warszawa 1999; M. Grabowska, Boskie i cesarskie. Religijność oraz stosunki między państwem a Kościołem a zachowania polityczne, w: Wybory parlamentarne $1997 . .$. 
rozbiorowych i związanych ze zmianą granic po 1945 r.) $)^{3}$. Oryginalną koncepcję zróżnicowania postaw wyborczych jako skutku „cywilizacyjnego rozdarcia kraju” przedstawił Mariusz Kowalski ${ }^{4}$. W badaniach dotyczących geograficznego aspektu postaw wyborczych brano pod uwagę przede wszystkim dane regionalne, agregowane najczęściej na poziomie okręgów wyborczych lub dawnych województw ${ }^{5}$, a rzadko - na poziomie gmin i powiatów.

Imponujące studia operujące na poziomie obwodów wyborczych dużych miast przedstawili Grzegorz Węcławowicz, Andrzej Jarosz i Przemysław Śleszyński - odnośnie do Warszawy ${ }^{6}$ i Marek Sobczyński - Łodzi. Pewną wadą tych badań, zwłaszcza w perspektywie politologicznej, była nadmierna koncentracja na analizie partii „zwycięskich”, co w przypadku ordynacji proporcjonalnej nie pozwala wyrobić sobie opinii na temat preferencji wyborczych, zwłaszcza w sytuacji dużego rozdrobnienia partii centroprawicowych w wyborach w 1991 i 1993 roku.

$\mathrm{Na}$ wyobraźnię szerokiego kręgu obserwatorów i uczestników rywalizacji politycznej najsilniej oddziaływały publikowane w mediach i opracowaniach naukowych mapy przedstawiające terytorialny wynik rywalizacji. To im zawdzięczamy w dużej mierze karierę tez na temat tego, że głosują „dwie Polski” - choć wynik na mapie pokazuje jedynie zwycięzcę, a nie przewagę czy dominację. Prezentacja map sprawia też, że dużą wagę przywiązuje się do podziałów rozbiorowych, lekceważąc te dane, które nieco psują spójny obraz.

Uważniejsi badacze zwracali jednak uwagę na to, że taka forma graficzna prezentacji przestrzennego rozkładu poparcia dla partii powoduje skupienie uwagi na preferencjach mieszkańców wsi i małych miast. By wyjaśnić skalę złudzenia, należy porównać dwa fakty - powierzchnia miast na prawach powiatu stanowi 2,3\% powierzchni kraju, a ludność mieszkająca w tych miastach - 32,9\% ludności Polski ${ }^{8}$.

3 J. Bartkowski, Tradycja i polityka. Wpływ tradycji kulturowych polskich regionów na wspótczesne zachowania społeczne i polityczne, Warszawa 2003.

4 M. Kowalski, Polaryzacja zachowań wyborczych jako rezultat cywilizacyjnego rozdarcia kraju, w: Przestrzeń wyborcza Polski, red. M. Kowalski, Warszawa 2013.

5 J. Raciborski, Polskie wybory. Zachowania wyborcze spoleczeństwa polskiego $w$ latach 1989-1995, Warszawa 1997.

6 G. Węcławowicz, A. Jarosz, P. Śleszyński, Atlas Warszawy, z. 5, Wybory parlamentarne 1991 i 1993, Warszawa 1998.

7 M. Sobczyński, Zróżnicowanie przestrzenne postaw politycznych mieszkańców Łodzi, Łódź 2000.

8 Główny Urząd Statystyczny, Powierzchnia i ludność Polski w przekroju terytorialnym w 2014 r., Warszawa 2015, s. 28. 
Jarosław Flis, dokonując typologii zachowań wyborczych, dzieli jednostki terytorialne na sześć grup, obok trzech zaborów i ziem włączonych do Polski po roku 1945 wyróżnia także metropolie i pozostałe miasta na prawach powiatu9. Wbrew pozorom ani metropolie, ani miasta na prawach powiatu nie tworzą jednak jednostek podobnych pod względem wyników wyborów. Zatem wyłączenie to ma w szerszym wymiarze sens jedynie negatywny, który można rozumieć tak, iż jednostki te nie pasują do modelu. W innym miejscu Flis wiąże zresztą wzory zachowań z poziomem urbanizacji - najniższy w powiatach ziemskich Galicji, najwyższy na ziemiach zachodnich ${ }^{10}$. By jednak teza ta mogła zostać wzięta pod uwagę, należałoby wykazać, że istnieje rzeczywista różnica między wynikami wyborów w małych miastach województwa lubuskiego czy zachodniopomorskiego a zachowaniami mieszkańców wsi, a jej poziom pozwala tłumaczyć odmienność od wyników mierzonych w skali powiatu w porównaniu z województwem podkarpackim czy małopolskim. Tak jednak nie jest.

Inny przykład analizy wychodzącej nie od zachowań wyborczych mieszkańców miast, ale od kategorii utworzonych na podstawie podobieństw cech społeczno-ekonomicznych stworzył Andrzej Lisowski ${ }^{11}$. Obserwacje poczynione na tej podstawie w niewielkim jednak stopniu poszerzają wiedzę politologów o rzeczywistych różnicach zachowań w dłuższym okresie, potwierdzając raczej intuicyjne rozumienie zależności między wielkością danego ośrodka a skłonnością głosowania na główne rywalizujące partie. W badaniach tego typu podstawowym ryzykiem jest jednak - na co zwracają uwagę w podstawowym tekście dotyczącym studiów nad geografią wyborczą Elżbieta Kabath i Zbigniew Rykiel - możliwość nieadekwatnego doboru zmiennych objaśniających ${ }^{12}$.

Niniejsze opracowanie zostało oparte zatem na odwrotnej metodzie. Nie poszukiwano objaśniających zachowania wyborcze cech społeczno-gospodarczych, ale przede wszystkim próbowano ustalić cechy podobieństwa między różnymi aktami głosowania. Profile wyborcze miast można klasyfikować na podstawie przeprowadzonych w szerszej perspektywie obserwacji. I choć nie mamy

9 J. Flis, Zludzenia wyboru. Spoteczne wyobrażenia i instytucjonalne ramy w wyborach do Sejmu i Senatu, Kraków 2014, s. 120-132.

10 J. Flis, Galicyjskie odmienności wyborcze, w: Szkoty polskiej demokracji, red. A. Wołek, Kraków 2014, s. 125.

11 A. Lisowski, Zróżnicowanie społeczne $i$ zachowania wyborcze $w$ wybranych miastach w Polsce, „Prace i Studia Geograficzne” 2009, t. 42, s. 103-133.

12 E. Kabath, Z. Rykiel, Metody badań geografii wyborczej i ich wyniki, w: Problemy interpretacji wyników metod badawczych stosowanych $w$ geografii społeczno-ekonomicznej i gospodarce przestrzennej, red. H. Rogacki, Poznań 2003, s. 143. 
możliwości porównań na taką skalę, na jaką uczynili to czescy politolodzy w przypadku Brna, przeprowadzając rozległe porównania obejmujące lata 1907$2006^{13}$, to jednak porównania $\mathrm{w}$ skali szerszej niż ostatnie wybory są $-\mathrm{z}$ wszelkimi zastrzeżeniami metodologicznymi - możliwe.

\section{Glosowanie i elektoraty}

By zbudować podstawową typologię zachowań mieszkańców miast, należało wybrać kilka oddalonych od siebie w czasie głosowań, a następnie zestawić dane w sposób dający się wykorzystać do tworzenia grup miast. Druga faza badania obejmowała weryfikację zaproponowanej typologii przez odniesienie jej do pozostałych wyborów.

Podstawową klasyfikację oparto na analizie trzech przypadków drugiej tury wyborów prezydenckich w 1995, 2005 i 2015 roku. W drugiej kolejności zbadano wyniki trzech elekcji sejmowych - także oddalonych od siebie o równe 10-letnie okresy: w 1991, 2001 i 2011 roku.

Za kluczowe uznano wyniki wyborów odzwierciedlające dwa podstawowe wzorce rywalizacji - historyczny między postkomunistami a dawną opozycją $(1995,2001)$ oraz między PiS a PO $(2005,2011,2015)$. Pierwszy podział najlepiej oddają dane dotyczące rywalizacji między Lechem Wałęsą a Aleksandrem Kwaśniewskim w drugiej turze wyborów prezydenckich w 1995 roku, a apogeum wpływów formacji postkomunistycznej dobrze oddają wyniki wyborów sejmowych z 2001 roku.

Gdy chodzi o rywalizację między PO a PiS, trzy punkty pomiaru pozwalają obserwować jej początkowy okres (prezydenckie 2005), dominację Platformy (sejmowe 2011) i ostatni dostępny moment tej rywalizacji (prezydenckie 2015), zmieniający trend, z jakim mieliśmy do czynienia w kolejnych wyborach po 2005 roku' ${ }^{14}$.

W przypadku danych dotyczących wyborów prezydenckich dysponujemy wygodnym jednoczynnikowym wskaźnikiem, jakim jest wynik drugiej tury, wskazujący zwycięzcę wyborów w danym mieście i jego przewagę nad rywalem. We wszystkich trzech przypadkach posłużyłem się prostą skalą, obejmującą wyraźne zwycięstwo jednego z rywali (powyżej 10 p.p.) oraz zwycięstwo

13 J. Kyloušek, M. Pink, J. Šedo, Volební mapa města Brna, Brno 2007.

14 Szerzej na temat wzorców rywalizacji zob. R. Matyja, Rywalizacja polityczna w Polsce, Kraków-Rzeszów 2013. Tam też omówiłem znaczenie osi rywalizacji prezydenckiej dla kształtowania się rywalizacji partyjnej i zachowań wyborców. 
umiarkowane (poniżej 10 p.p.). W tabeli 1 zaprezentowano dane dotyczące 1995 i 2005 roku, a w tabeli 3 - różnice między 2005 a 2015 rokiem.

Tabela 1. Grupy miast, w których wygrali kandydaci w drugiej turze wyborów prezydenckich w 1995 i 2005 roku

\begin{tabular}{|l|c|c|c|c|}
\hline \multicolumn{1}{|c|}{ Wygrana } & $\begin{array}{c}\text { Zdecydowana } \\
\text { wygrana Tuska }\end{array}$ & $\begin{array}{c}\text { Umiarkowana } \\
\text { wygrana Tuska }\end{array}$ & $\begin{array}{c}\text { Umiarkowana } \\
\text { wygrana } \\
\text { Kaczyńskiego }\end{array}$ & $\begin{array}{c}\text { Zdecydowana } \\
\text { wygrana } \\
\text { Kaczyńskiego }\end{array}$ \\
\hline $\begin{array}{l}\text { Zdecydowana wygrana } \\
\text { Kwaśniewskiego }\end{array}$ & 17 & 10 & 9 & 9 \\
\hline $\begin{array}{l}\text { Umiarkowana wygrana } \\
\text { Kwaśniewskiego }\end{array}$ & 4 & 2 & 4 & 7 \\
\hline $\begin{array}{l}\text { Umiarkowana wygrana } \\
\text { Wałęsy }\end{array}$ & 5 & 2 & 3 & 4 \\
\hline $\begin{array}{l}\text { Zdecydowana wygrana } \\
\text { Wałęsy }\end{array}$ & 13 & 4 & 6 & 8 \\
\hline
\end{tabular}

Zgodnie z opinią większości badaczy podział z roku 1995 można opisać w kategoriach prawica-lewica lub postkomunizm-antykomunizm ${ }^{15}$. Uważam jednak, że ten pierwszy lepiej oddaje preferencje wyborców, a drugi - uczestniczących w rywalizacji elit. Za określeniem ,prawicowość” przemawia fakt nakładania się osi dotyczącej oceny przeszłości na oś „,katolicyzm-laickość”.

Drugi podział, obowiązujący w 2005 i 2015 roku, opisywany jest jako spór między liberalizmem a konserwatyzmem albo autorytaryzmem. Jedna ze stron (PiS) określiła go niezwykle efektywnie jako spór „Polski solidarnej” i „Polski liberalnej”. W 2015 roku strona przeciwna (PO) próbowała wykorzystać podobne rozróżnienie posługując się hasłami „Polski racjonalnej” i „Polski radykalnej”. Wszystkie te określenia niosą ze sobą silny ładunek emocjonalny i bywają używane do deprecjonowania jednej ze stron. W artykule dlatego wykorzystano bardziej neutralną opozycję liberalny-nieliberalny.

W tabeli 1 zestawiono ze sobą wyniki drugich tur wyborów prezydenckich w 1995 i 2005 roku. Miasta podzielono na cztery grupy: w przypadku wyborów w 1995 roku na miasta, w których zdecydowanie wygrał Aleksander Kwaśniewski (z przewagą wyższą niż 10 p.p., a zatem zdobywając więcej niż 55\% ważnych głosów), na te, w których wygrał umiarkowanie, (nie więcej niż 10 p.p., a zatem

15 Por. m.in. T. Szawiel, Podział lewica-prawica $w$ polityce oraz $w$ szerszym kontekście kulturowym, w: M. Grabowska, T. Szawiel, Budowanie demokracji. Podziały społeczne, partie polityczne i społeczeństwo obywatelskie w postkomunistycznej Polsce, Warszawa 2001. 
zdobywając między 50\% a 55\% głosów) oraz na te, w których umiarkowanie lub zdecydowanie wygrał Lech Wałęsa (zdobywając podobnie wynik między 50\% a 55\% i powyżej 55\%). Podobną zasadę przyjęto w przypadku drugiej tury wyborów prezydenckich w 2005 roku, zestawiający wyniki Lecha Kaczyńskiego i Donalda Tuska. W tabeli 2 przedstawiono szczegółowy spis miast, zaprezentowany w sposób ułatwiający jej porównywanie z danymi dotyczącymi wyborów sejmowych ujętych w tabeli 2, w której wskazano inicjały poszczególnych kandydatów.

Na podstawie zgromadzonych w tabeli 2 danych można wyróżnić cztery kategorie podstawowe, których typowi reprezentanci znajdować się będą w narożnych polach tabeli:

a) prawicową i nieliberalną, którą charakteryzować będzie połączenie zdecydowanej przewagi Lecha Wałęsy i Lecha Kaczyńskiego, do grupy tej należeć będą m.in. Lublin, Nowy Sącz i Rzeszów;

b) prawicową i liberalną, obejmującą miasta, w których obserwowaliśmy wysoką przewagę Lecha Wałęsy i Donalda Tuska; do grupy tej należeć będą m.in. Gdańsk, Kraków, Warszawa i Wrocław;

c) lewicową i liberalną, dla której cechą charakterystyczną jest wysoka przewaga Aleksandra Kwaśniewskiego i Donalda Tuska; miastami należącymi do tej grupy są m.in. Olsztyn, Wałbrzych i Zielona Góra;

d) lewicową i nieliberalną, którą cechują wysokie wygrane Aleksandra Kwaśniewskiego i Lecha Kaczyńskiego; do grupy tej należeć będą mniejsze miasta, m.in. Chełm, Sieradz i Suwałki.

Przyjrzyjmy się teraz liczebności poszczególnych grup. Zaznaczone grupy miast o wyrazistej przewadze dwóch wybranych opcji w wyborach prezydenckich stanowią łącznie mniej niż połowę miast w badanej grupie. Niezwykle ważne będzie dlatego dokonanie następnego kroku zmierzającego do dalszego precyzyjnego określenia badanych grup miast - analizy wyników drugiej tury wyborów prezydenckich w 2015 roku oraz wyborów sejmowych w 2001 i 2011 roku.

W tabeli 3 zaprezentowano zmiany zachowań - porównano różnicę poparcia dla kandydatów PiS i PO w wyborach prezydenckich w 2005 i 2015 roku. Potwierdzają one utrzymywanie się w 2015 roku zasadniczego podziału ukształtowanego w wyborach z 2005 roku. W przypadku 77 miast w zaznaczonych polach możemy mówić o utrzymaniu się zasadniczych postaw wyborców. Tylko w przypadku 2 miast - Krakowa i Lubina - Andrzejowi Dudzie udało się uzyskać wyższą kategorię niż Lechowi Kaczyńskiemu. W Krakowie Bronisław 
Komorowski uzyskał przewagę umiarkowaną, a przewaga Dudy w Lubinie była zdecydowana.

Tabela 2. Miasta, w których wygrali kandydaci

w drugiej turze wyborów prezydenckich w 1995 i 2005 roku

\begin{tabular}{|c|c|c|c|c|}
\hline Wygrana & Zdecydowana DT & Umiarkowana DT & Umiarkowana LK & Zdecydowana LK \\
\hline Zdecydowana AK & $\begin{array}{l}\text { Będzin } \\
\text { Bolesławiec } \\
\text { Gniezno } \\
\text { Grudziądz } \\
\text { Jelenia Góra } \\
\text { Kołobrzeg } \\
\text { Koszalin } \\
\text { Leszno } \\
\text { Nowa Sól } \\
\text { Olsztyn } \\
\text { Piła } \\
\text { Słupsk } \\
\text { Stargard Szcz. } \\
\text { Świdnica } \\
\text { Świnoujście } \\
\text { Wałbrzych } \\
\text { Zielona Góra }\end{array}$ & $\begin{array}{l}\text { Dąbrowa Górn. } \\
\text { Gorzów } \\
\text { Inowrocław } \\
\text { Jaworzno } \\
\text { Kalisz } \\
\text { Legnica } \\
\text { Ostrów Wlkp. } \\
\text { Sosnowiec } \\
\text { Włocławek } \\
\text { Zawiercie }\end{array}$ & $\begin{array}{l}\text { Ełk } \\
\text { Głogów } \\
\text { Kielce } \\
\text { Konin } \\
\text { Lubin } \\
\text { Płock } \\
\text { Skarżysko-Kam. } \\
\text { Skierniewice } \\
\text { Starachowice }\end{array}$ & $\begin{array}{l}\text { Bełchatów } \\
\text { Chełm } \\
\text { Ciechanów } \\
\text { Kutno } \\
\text { Ostrowiec Św. } \\
\text { Radomsko } \\
\text { Sieradz } \\
\text { Suwałki } \\
\text { Zduńska Wola }\end{array}$ \\
\hline Umiarkowana AK & $\begin{array}{l}\text { Elbląg } \\
\text { Kędzierzyn-Koźle } \\
\text { Łódź } \\
\text { Zabrze }\end{array}$ & $\begin{array}{l}\text { Bydgoszcz } \\
\text { Częstochowa }\end{array}$ & $\begin{array}{l}\text { Tomaszów Maz. } \\
\text { Zgierz } \\
\text { Żory } \\
\text { Żyrardów }\end{array}$ & $\begin{array}{l}\text { Biała Podlaska } \\
\text { Knurów } \\
\text { Ostrołęka } \\
\text { Piotrków Tryb. } \\
\text { Siedlce } \\
\text { Tarnobrzeg } \\
\text { Zamość }\end{array}$ \\
\hline Umiarkowana LW & $\begin{array}{l}\text { Bytom } \\
\text { Gliwice } \\
\text { Opole } \\
\text { Siemianowice Śl. } \\
\text { Szczecin }\end{array}$ & $\begin{array}{l}\text { Oświęcim } \\
\text { Toruń }\end{array}$ & $\begin{array}{l}\text { Mysłowice } \\
\text { Pabianice } \\
\text { Starogard Gd. }\end{array}$ & $\begin{array}{l}\text { Jastrzębie Zdrój } \\
\text { Mielec } \\
\text { Puławy } \\
\text { Radom }\end{array}$ \\
\hline Zdecydowana LW & $\begin{array}{l}\text { Chorzów } \\
\text { Gdańsk } \\
\text { Gdynia } \\
\text { Katowice } \\
\text { Kraków } \\
\text { Poznań } \\
\text { Racibórz } \\
\text { Sopot } \\
\text { Świętochłowice } \\
\text { Tczew } \\
\text { Warszawa } \\
\text { Wejherowo } \\
\text { Wrocław }\end{array}$ & $\begin{array}{l}\text { Bielsko-Biała } \\
\text { Legionowo } \\
\text { Pruszków } \\
\text { Tychy }\end{array}$ & $\begin{array}{l}\text { Białystok } \\
\text { Otwock } \\
\text { Piekary } \\
\text { Ruda Śląska } \\
\text { Rybnik } \\
\text { Wodzisław Śl. }\end{array}$ & $\begin{array}{l}\text { Krosno } \\
\text { Lublin } \\
\text { Łomża } \\
\text { Nowy Sącz } \\
\text { Przemyśl } \\
\text { Rzeszów } \\
\text { Stalowa Wola } \\
\text { Tarnów }\end{array}$ \\
\hline
\end{tabular}


Tabela 3. Grupy miast, w których wygrali kandydaci w drugiej turze wyborów prezydenckich w 2005 i 2015 roku

\begin{tabular}{|c|c|c|c|c|}
\hline Wygrana & Zdecydowana AD & Umiarkowana AD & Umiarkowana BK & Zdecydowana BK \\
\hline Zdecydowana LK & 15 & 11 & 1 & 0 \\
\hline Umiarkowana LK & 1 & 14 & 6 & 1 \\
\hline Umiarkowana DT & 0 & 0 & 11 & 9 \\
\hline Zdecydowana DT & 0 & 0 & 1 & 37 \\
\hline
\end{tabular}

Bronisławowi Komorowskiemu udało się aż w 28 miastach uzyskać korzystniejszy efekt niż Donaldowi Tuskowi. W 11 przypadkach osłabił przewagę konkurenta z PiS, w siedmiu dalszych zamienił porażkę na zwycięstwo, a w 10 umiarkowane zwycięstwo na zdecydowane. Zmiany te będą podstawą korekt czterech wymienionych wyżej grup bazowych. Zasadniczej korekty i ostatecznego przyporządkowania dokonamy porównując wyniki dwóch elekcji sejmowych.

Ta pierwsza, to moment największego zwycięstwa Sojuszu Lewicy Demokratycznej i apogeum wpływów tej partii. Druga - to ponowne zwycięstwo wyborcze Platformy, odniesione w warunkach bardziej stabilnych niż przedterminowe wybory parlamentarne w 2007 roku. Wyniki tych dwóch partii są podstawą zaprezentowanej niżej klasyfikacji. W przypadku wyborów sejmowych sprawa okazuje się nieco bardziej skomplikowana metodologicznie. Nie ma bowiem równie czytelnych danych, jak wyniki drugiej tury wyborów prezydenckich.

W przypadku wyborów w 2001 roku za kluczowy można uznać wynik list SLD-UP, nie porównując go z jakimkolwiek innym komitetem. Podobnie w 2011 roku, punktem odniesienia będzie wynik Platformy. W ten sposób uzyskamy analogiczny do zbudowanego na podstawie wyborów prezydenckich sposób grupowania miast. Miasta należące do kategorii zaznaczonych w tabeli 4 kolorem szarym można ponownie uznać za reprezentujące cechy czterech głównych grup, omówionych poprzednio.

Tabela 4. Grupy miast, według odsetka wyborców popierających SLD w wyborach 2001 roku i PO - w 2011 roku

\begin{tabular}{|c|c|c|c|c|c|}
\hline $\begin{array}{c}\text { Wynik } \\
\text { ugrupowania }\end{array}$ & PO $>50 \%$ & PO $45-50 \%$ & PO $40-45 \%$ & PO 35-40\% & PO $<35 \%$ \\
\hline SLD $>55 \%$ & 2 & 6 & 6 & 2 & 2 \\
\hline SLD 50-55\% & 3 & 8 & 5 & 7 & 4 \\
\hline SLD 45-50\% & 1 & 7 & 7 & 2 & 4 \\
\hline SLD 40-45\% & 7 & 4 & 3 & 0 & 7 \\
\hline SLD $<40 \%$ & 5 & 6 & 3 & 3 & 3 \\
\hline
\end{tabular}


W tabeli 5 pokazano przynależność konkretnych miast prezydenckich do poszczególnych grup. Dodatkowo zaznaczono w niej informacje dotyczące wysokich wyników PiS (powyżej 35\% pogrubione i podkreślone, powyżej 30\% tylko podkreślone) oraz połączonych list SLD i Ruchu Palikota (powyżej 30\% - pogrubione i kursywa, powyżej 25\% - tylko kursywa). Pozwala to na uniknięcie pewnych błędów w odczytaniu danych. Przykładem niech będzie Gniezno, które na podstawie danych w tabeli 5 bez zaznaczenia dodatkowych cech można by uznać za miasto „lewicowe i nieliberalne”, podczas gdy niski wynik PO jest

Tabela 5. Miasta, według odsetka wyborców popierających SLD w wyborach 2001 i PO w 2011 roku

\begin{tabular}{|c|c|c|c|c|c|}
\hline Wynik & $\mathrm{PO}>50 \%$ & PO $45-50 \%$ & PO $40-45 \%$ & PO $35-40 \%$ & $\mathrm{PO}<35 \%$ \\
\hline $\begin{array}{l}\text { SLD } \\
>55 \%\end{array}$ & $\begin{array}{l}\text { Grudziądz } \\
\text { Leszno }\end{array}$ & $\begin{array}{l}\text { Będzin } \\
\text { Inowroctaw } \\
\text { Jelenia Góra } \\
\text { Stargard Szcz. } \\
\text { Świnoujście } \\
\text { Wałbrzych }\end{array}$ & $\begin{array}{l}\text { Dábrowa Górn. } \\
\text { Legnica } \\
\text { Ostrów Wlkp. } \\
\text { Sosnowiec } \\
\text { Włocławek } \\
\text { Zawiercie }\end{array}$ & $\frac{\text { Glogów }}{\text { Gniezno }}$ & $\begin{array}{l}\text { Ostrowiec Św. } \\
\text { Starachowice }\end{array}$ \\
\hline $\begin{array}{l}\text { SLD } \\
50-55 \%\end{array}$ & $\begin{array}{l}\text { Kołobrzeg } \\
\text { Nowa Sól } \\
\text { Zabrze }\end{array}$ & \begin{tabular}{|l|} 
Bolesławiec \\
Bydgoszcz \\
Elbląg \\
Jaworzno \\
Łódź \\
Piła \\
Słupsk \\
Zielona Góra
\end{tabular} & $\begin{array}{l}\text { Gorzów Wlkp. } \\
\text { Kalisz } \\
\text { Knurów } \\
\text { Skierniewice } \\
\text { Tarnobrzeg }\end{array}$ & $\begin{array}{l}\text { Kielce } \\
\text { Konin } \\
\text { Kutno } \\
\text { Płock } \\
\text { Sieradz } \\
\text { Skarżysko- } \\
\text { Kam. } \\
\text { Zduńska Wola }\end{array}$ & $\begin{array}{l}\frac{\text { Ciechanów }}{\text { Jastrzębie }} \\
\text { Lubin } \\
\underline{\text { Radomsko }}\end{array}$ \\
\hline $\begin{array}{l}\text { SLD } \\
45-50 \%\end{array}$ & Siemianowice & $\begin{array}{l}\text { Bytom } \\
\text { Koszalin } \\
\text { Olsztyn } \\
\text { Szczecin } \\
\text { Świdnica } \\
\text { Świętochłowice } \\
\text { Żyrardów } \\
\end{array}$ & $\begin{array}{l}\text { Ełk } \\
\text { Mysłowice } \\
\text { Oświęcim } \\
\text { Pabianice } \\
\text { Ruda Śl. } \\
\text { Zgierz } \\
\text { Żory }\end{array}$ & $\begin{array}{l}\text { Częstochowa } \\
\text { Tomaszów Maz. }\end{array}$ & $\begin{array}{l}\text { Belchatów } \\
\text { Chetm } \\
\text { Piotrków Tryb. } \\
\underline{\text { Suwałki }}\end{array}$ \\
\hline $\begin{array}{l}\text { SLD } \\
40-45 \%\end{array}$ & $\begin{array}{l}\text { Chorzów } \\
\text { Gliwice } \\
\text { Katowice } \\
\text { Kędzierzyn-K. } \\
\text { Opole } \\
\text { Poznań } \\
\text { Racibórz }\end{array}$ & $\begin{array}{l}\text { Legionowo } \\
\text { Toruń } \\
\text { Tychy } \\
\text { Wodzisław }\end{array}$ & $\begin{array}{l}\underline{\text { Białystok }} \\
\text { Przemyśl } \\
\underline{\text { Starogard Gd. }}\end{array}$ & & $\begin{array}{l}\text { Biala Podlaska } \\
\text { Mielec } \\
\text { Ostrołeka } \\
\text { Radom } \\
\text { Rzeszów } \\
\text { Siedlce } \\
\text { Zamość } \\
\end{array}$ \\
\hline $\begin{array}{l}\text { SLD } \\
<40 \%\end{array}$ & \begin{tabular}{|l} 
Gdańsk \\
Gdynia \\
Sopot \\
Wejherowo \\
Wrocław
\end{tabular} & $\begin{array}{l}\text { Bielsko-Biała } \\
\text { Kraków } \\
\text { Piekary Śl. } \\
\text { Rybnik } \\
\text { Tczew } \\
\text { Warszawa }\end{array}$ & $\begin{array}{l}\text { Pruszków } \\
\text { Puławy } \\
\text { Tarnów }\end{array}$ & $\begin{array}{l}\text { Krosno } \\
\text { Nowy Sacz } \\
\underline{\text { Otwock }}\end{array}$ & $\begin{array}{l}\text { Lublin } \\
\text { Lomża } \\
\text { Stalowa Wola } \\
\end{array}$ \\
\hline
\end{tabular}


związany przede wszystkim z wyjątkowo wysokim odsetkiem głosujących na dwie listy lewicowe. W przypadku znajdującego się w tym samym polu Głogowa - mamy do czynienia z wysokimi wynikami lewicy (choć nie tak wysokim jak Gnieźnie) i PiS. A zatem to miasto będzie reprezentować cechy, które przesądzają o przynależności do tej grupy. Gniezno zaś można uznać za reprezentujące cechy grup (a) i (d).

Na podstawie dwóch kluczowych dla niniejszego badania tabel 2 i 5 można sporządzić podział miast na grupy. W każdej ze wskazanych wyżej grup znajdą się dwie podgrupy - reprezentująca jej cechy w sposób wyrazisty oraz niepełny. Miasta, które reprezentują cechy charakterystyczne dla różnych grup lub znalazły się dwukrotnie w środku obu tabel, uznamy za miasta „centrowe” i utworzymy z nich osobną piątą kategorię.

\section{Profile wyborcze miast i ich weryfikacja}

Na podstawie analizy przeprowadzonej dotychczas można stworzyć pięć zasadniczych wzorów zachowań i podzielić miasta na dziewięć następujących grup: lewicowo-liberalne (wyraźnie i niepełne oznaczane dalej jako A i Aa), prawicowo-liberalne (B i Bb), prawicowe i nieliberalne ( $\mathrm{C}$ i Cc), oraz lewicowe i nieliberalne (D i Dd). Ostatnią kategorię miast tworzą te, w których preferencje mieszkańców lokują się niemal zawsze w centrum tabeli, nie pozwalając na wyraźną ocenę przynależności do którejkolwiek z grup.

Tabela 6. Profile miast określone na podstawie tabel 2 i 5

\begin{tabular}{|c|c|c|}
\hline Cecha zachowań & Wyraźna & Niepełna \\
\hline 1 & 2 & 3 \\
\hline $\begin{array}{l}\text { Lewicowe, liberalne } \\
\text { A i Aa }\end{array}$ & $\begin{array}{l}15 \text { miast - Będzin, Bolesławiec, } \\
\text { Grudziądz, Inowrocław, Jelenia } \\
\text { Góra, Kołobrzeg, Leszno, Nowa } \\
\text { Sól, Piła, Słupsk, Stargard, } \\
\text { Świnoujście, Wałbrzych, Zabrze, } \\
\text { Zielona Góra }\end{array}$ & $\begin{array}{l}\mathbf{1 7} \text { miast - Bydgoszcz, Dąbrowa } \\
\text { Górnicza, Elbląg, Gniezno, Gorzów } \\
\text { Wielkopolski, Jaworzno, Kalisz, } \\
\text { Koszalin, Legnica, Łódź, Olsztyn, } \\
\text { Ostrów W., Sosnowiec, Szczecin, } \\
\text { Świdnica, Włocławek, Zawiercie }\end{array}$ \\
\hline $\begin{array}{l}\text { Prawicowe, liberalne } \\
\mathrm{B} \mathrm{i} \mathrm{Bb}\end{array}$ & $\begin{array}{l}13 \text { miast - Chorzów, Gdańsk, } \\
\text { Gdynia, Katowice, Kraków, } \\
\text { Opole, Poznań, Racibórz, Sopot, } \\
\text { Tczew, Warszawa, Wejherowo, } \\
\text { Wrocław }\end{array}$ & $\begin{array}{l}12 \text { miast - Bielsko-Biała, Bytom, } \\
\text { Gliwice, Kędzierzyn-Koźle, } \\
\text { Legionowo, Piekary Śl., Rybnik, } \\
\text { Siemianowice, Świętochłowice, } \\
\text { Toruń, Tychy, Wodzisław Śl. }\end{array}$ \\
\hline
\end{tabular}




\begin{tabular}{|c|c|c|}
\hline 1 & 2 & 3 \\
\hline $\begin{array}{l}\text { Prawicowe, nieliberalne } \\
\text { C i Cc }\end{array}$ & $\begin{array}{l}8 \text { miast - Krosno, Lublin, Łomża, } \\
\text { Mielec, Nowy Sącz, Radom, } \\
\text { Rzeszów, Stalowa Wola }\end{array}$ & $\begin{array}{l}10 \text { miast - Biała Podlaska, Białystok, } \\
\text { Ostrołęka, Otwock, Pruszków, } \\
\text { Przemyśl, Puławy, Siedlce, Tarnów, } \\
\text { Zamość }\end{array}$ \\
\hline $\begin{array}{l}\text { Lewicowe, nieliberalne } \\
\text { D i Dd }\end{array}$ & $\begin{array}{l}9 \text { miast - Bełchatów, Chełm, } \\
\text { Ciechanów, Kutno, Lubin, } \\
\text { Ostrowiec Św., Radomsko, } \\
\text { Sieradz, Starachowice }\end{array}$ & $\begin{array}{l}12 \text { miast - Głogów, Jastrzębie Zdrój, } \\
\text { Kielce, Knurów, Konin, Piotrków } \\
\text { Trybunalski, Płock, Skierniewice, } \\
\text { Skarżysko-Kamienna, Suwałki, } \\
\text { Tarnobrzeg, Zduńska Wola }\end{array}$ \\
\hline $\begin{array}{l}\text { Centrowe } \\
\text { E }\end{array}$ & \multicolumn{2}{|c|}{$\begin{array}{l}11 \text { miast - Częstochowa, Ełk, Mysłowice, Oświęcim, Pabianice, Ruda } \\
\text { Śląska, Starogard Gd., Tomaszów Maz., Zgierz, Żory, Żyrardów }\end{array}$} \\
\hline
\end{tabular}

Oczywiście podział ten należy uznać za wstępną propozycję typologii, której zasadność powinna zostać zweryfikowana przy użyciu danych dotyczących wszystkich wyborów. Na potrzeby niniejszego tekstu, badającego zależność profilów wyborczych miast i wyników wyborów ich prezydentów, to pogrupowanie uznamy za wystarczające po przeprowadzeniu jedynie uproszczonej weryfikacji, dającej jednak pewne pojęcie o wadach przyjętej metodologii i warunkach jej stosowalności. Oceny dokonamy badając miasta, w których najsilniejsi kandydaci w I turach wyborów prezydenckich i najsilniejsze ugrupowania w wyborach sejmowych zdobywały najwyższy odsetek głosów.

\section{Problem wyborów założycielskich}

Wybory w 1991 roku uznaje się w literaturze za wybory założycielskie ${ }^{16}$, a podstawowa trudność z interpretacją danych ich dotyczących wynika z dużej liczby uczestniczących partii. I choć publicystyczna formuła mówiąca o kilkudziesięciu ugrupowaniach jest przesadzona, to obliczona, choćby za pomocą indeksu Laakso i Taagepery, efektywna liczba partii rywalizujących w poszczególnych miastach prezydenckich waha się między 6 a 13. Bardzo trudno dlatego byłoby znaleźć sensowne kryteria określania na podstawie wyników z 1991 roku poszczególnych grup miast. Nawet dość sensowny wskaźnik, jakim jest łączny wynik partii centroprawicowych, zaprezentowany w tabeli 6 okazuje się być zawodny. W wyborach w 1991 roku istotne są bowiem dwa czynniki - wysoki poziom personalnej identyfikacji ugrupowań i trudności w dokonaniu wyboru z tak dużej i niepoddanej wstępnej hierarchizacji liczby ofert.

16 M.in. P.G. Lewis, Political parties in Post-Communist Eastern Europe, London-New York 2000, s. 27. 
Mimo to, tylko kilka wyników w tabeli 7 można uznać za niezgodne z cechami miast opisanymi w tabeli 6. Do takich zaliczymy wysokie wynik Unii Demokratycznej w Przemyślu (24\%), Kongresu Liberalno-Demokratycznego w Knurowie (16\%). Zauważmy jednak, że w tym samym Knurowie wysoki wynik odnotowała także lista KPN (17\%). Nie można zatem jedynie na podstawie odsetka poparcia dla poszczególnych partii budować żadnych uogólnień. A każda próba sumowania wyników kilku list będzie z punktu widzenia niniejszego badania ryzykowna.

Osobną kwestią są bardzo wysokie wyniki związkowej listy „Solidarności” w miastach, które określam tu mianem prawicowo-liberalnych, w latach 20052015 cechujących się wysokim poziomem poparcia dla Platformy Obywatelskiej i jej kandydatów na urząd prezydenta. Warto jednak pamiętać, że poparcie to było w znaczącej części wyrazem przywiązania do silnego w regionie gdańskim przywiązania do tradycji ,Solidarności” jako ruchu opozycji lat osiemdziesiątych XX wieku. W późniejszych latach mogło zatem owocować poparciem dla różnych nurtów politycznych o rodowodzie solidarnościowym. Inna ciekawa prawidłowość, to wysokie wyniki PSL w miastach grupy D.

Tabela 7. Miasta, w których odnotowano najwyższy odsetek poparcia dla ugrupowań W roku $1991(\mathrm{w} \%)$

\begin{tabular}{|c|c|c|}
\hline Sojusz Lewicy Demokratycznej & Unia Demokratyczna & $\begin{array}{c}\text { Kongres Liberalno- } \\
\text {-Demokratyczny }\end{array}$ \\
\hline 1 & 2 & 3 \\
\hline A - Inowrocław $-33,3$ & B - Opole $-25,7$ & B-Sopot $-23,2$ \\
\hline D - Ostrowiec Św. - 31,9 & B - Kraków - 24,9 & B - Gdańsk - 21,8 \\
\hline Aa - Włocławek - 24,7 & B - Wrocław $-24,2$ & B - Gdynia - 19,8 \\
\hline $\mathrm{Aa}-$ Kalisz $-24,6$ & Cc-Przemyśl - 24,1 & B - Katowice $-16,7$ \\
\hline D - Ciechanów - 24,0 & A - Świnoujście $-22,4$ & B - Warszawa $-16,6$ \\
\hline D - Kutno $-23,5$ & $\mathrm{Bb}-$ Gliwice $-21,8$ & Bb - Piekary Śląskie - 16,3 \\
\hline $\mathrm{Aa}-$ Sosnowiec $-23,4$ & Aa - Ostrów Wlkp.-21,7 & Dd - Knurów - 16,2 \\
\hline NSZZ Solidarność & Konfederacja Polski Niepodl. & Polskie Stronnictwo Ludowe \\
\hline $\mathrm{B}-\mathrm{Tczew}-20,2$ & Dd - Jastrzębie Zdrój 24,3 & D - Kutno $-13,4$ \\
\hline B - Wejherowo - 16,6 & $\mathrm{E}-$ Żory $-23,3$ & D - Ciechanów - 7,1 \\
\hline B - Gdynia - 16,5 & Cc - Puławy - 19,2 & A - Zielona Góra - 7,0 \\
\hline B - Gdańsk - 16,2 & B - Kraków $-17,3$ & Dd - Skierniewice $-6,8$ \\
\hline $\mathrm{Aa}-\mathrm{Bydgoszcz}-16,0$ & Dd - Knurów - 17,1 & $D-$ Sieradz $-5,9$ \\
\hline C-Mielec $-14,8$ & D - Bełchatów - 16,2 & Dd - Płock $-5,8$ \\
\hline Dd - Tarnobrzeg - 14,4 & $\mathrm{C}-$ Lublin $-16,1$ & D - Radomsko $-5,7$ \\
\hline
\end{tabular}




\begin{tabular}{|c|c|c|}
\hline 1 & 2 & 3 \\
\hline Porozumienie Ob. Centrum & Wyborcza Akcja Katolicka & Centroprawica \\
\hline D - Starachowice $-23,2$ & C- Łomża - 29,1 & $\mathrm{C}-$ Łomża $-45,1$ \\
\hline C - Nowy Sącz - 23,2 & $\mathrm{Cc}$ - Ostrołęka - 26,7 & $\mathrm{Cc}-$ Otwock $-42,6$ \\
\hline $\mathrm{Aa}-$ Elbląg $-21,0$ & C- Radom - 20,6 & B - Wejherowo - 39,6 \\
\hline Cc - Przemyśl - 17,6 & E - Pabianice $-18,6$ & Aa - Gorzów Wlkp. - 39,4 \\
\hline $\mathrm{Cc}-$ Białystok $-17,0$ & Aa - Gorzów Wlkp. - 18,1 & $\mathrm{Cc}-$ Ostrołęka - 39,2 \\
\hline $\mathrm{Bb}$ - Legionowo - 16,4 & $\mathrm{Cc}-$ Otwock $-17,5$ & C - Nowy Sącz - 38,5 \\
\hline Cc - Otwock - 16,2 & Cc - Biała Podlaska - 17,1 & Cc - Biała Podlaska - 37,2 \\
\hline
\end{tabular}

Listy, które uwzględniłem obliczając wynik centroprawicy, obejmują: Porozumienie Obywatelskie Centrum, Wyborczą Akcję Katolicką, NSZZ „Solidarność”, Porozumienie Ludowe i Chrześcijańską Demokrację oraz niektóre listy lokalne o wyraźnym obliczu centroprawicowym.

Dla porównania można wziąć pod uwagę jeszcze wyniki pierwszej tury wyborów prezydenckich z 1990 roku, gdzie zaobserwujemy więcej prawidłowości. Wśród miast z najwyższym odsetkiem głosów oddanych na Lecha Wałęsę będą miasta z dwóch grup ,prawicowych”, a w przypadku Tadeusza Mazowieckiego miasta z dwóch grup „liberalnych”. Nieco bardziej złożona jest kwestia grupy miast, w których najwyższe poparcie odnotował Stanisław Tymiński. To z jednej strony „nieliberalne” i „lewicowe” miasta z grupy D, a także miasta „lewicowe” i „liberalne" leżące na terenie Zagłębia, z późniejszym silnym poparciem dla list SLD.

Tabela 8. Miasta z najwyższym poparciem dla kandydatów w I turze wyborów prezydenckich 1990 roku (w \%)

\begin{tabular}{|c|c|c|}
\hline Lech Wałęsa & Stanisław Tymiński & Tadeusz Mazowiecki \\
\hline Cc - Otwock $-59,2$ & $\mathrm{E}-$ Żory $-50,1$ & B - Poznań - 37,8 \\
\hline B - Gdańsk - 57,4 & Dd - Jastrzębie-Zdrój - 47,4 & B - Opole $-37,6$ \\
\hline $\mathrm{C}-$ Radom $-56,0$ & D- Bełchatów - 42,9 & $\mathrm{Aa}-$ Szczecin $-35,7$ \\
\hline B - Sopot $-53,5$ & Dd - Knurów - 42,7 & $\mathrm{Bb}-$ Gliwice $-35,2$ \\
\hline B - Wejherowo - 52,2 & D - Kutno $-41,1$ & A - Świnoujście $-34,2$ \\
\hline $\mathrm{C}$ - Nowy Sącz $-52,0$ & A - Będzin - 39,9 & B - Kędzierzyn-Koźle - 33,2 \\
\hline B - Gdynia - 51,3 & $\mathrm{Cc}$ - Ostrołęka - 39,7 & A - Zielona Góra - 33,2 \\
\hline $\mathrm{Bb}-$ Legionowo $-51,2$ & Aa - Dąbrowa Górnicza - 39,6 & B - Katowice $-33,1$ \\
\hline Cc - Pruszków - 50,6 & Aa - Sosnowiec $-38,4$ & B - Kraków $-31,9$ \\
\hline Cc - Zamość - 50,6 & Aa - Zawiercie $-38,3$ & A - Zabrze $-31,7$ \\
\hline
\end{tabular}




\section{Późniejsza weryfikacja 1997-2010}

Kolejnym krokiem w procedurze weryfikacji będzie przyjrzenie się miastom z najwyższym odsetkiem poparcia dla kandydatów w I turze wyborów prezydenckich w 2000 i 2010 roku (tab. 9). W obu przypadkach wzięto pod uwagę trzech kandydatów z najwyższymi wynikami. W przypadku danych dotyczących 2000 roku znajdujemy tylko jeden wynik, odbiegający od wzorca ustalonego powyżej - dotyczy wysokiego poparcia, jakie Marianowi Krzaklewskiemu udzielili mieszkańcy Wejherowa. Pamiętajmy jednak, że w mieście tym dominował elektorat „solidarnościowy” i „,antykomunistyczny”, który w konkretnych realiach wyborczych mógł głosować nadal „na AWS”, a dopiero po rozpadzie tej formacji i powstaniu PO i PiS określił się jako bardziej liberalny.

Tabela 9. Miasta z najwyższym poparciem dla kandydatów w I turze wyborów prezydenckich w latach 2000 i 2010 (w \%)

\begin{tabular}{|c|c|c|}
\hline Aleksander Kwaśniewski & Andrzej Olechowski & Marian Krzaklewski \\
\hline $\begin{array}{l}\text { A - Będzin - 74,8 } \\
\text { Aa - Dąbrowa Górnicza - 74,7 } \\
\text { Aa - Zawiercie - 73,9 } \\
\text { Aa - Sosnowiec }-73,7 \\
\text { A - Inowrocław - 72,5 } \\
\text { A - Wałbrzych - 71,2 } \\
\text { D - Ostrowiec Św. }-70,8 \\
\text { A - Grudziądz - 69,1 } \\
\text { Aa - Włocławek - 68,6 } \\
\text { D - Starachowice }-67,4\end{array}$ & $\begin{array}{l}\text { B - Sopot - 37,0 } \\
\text { B - Gdańsk - 31,3 } \\
\text { B - Gdynia - 29,9 } \\
\text { Cc - Otwock - 27,4 } \\
\text { Cc- Tarnów - 26,9 } \\
\text { B - Poznań - 26,8 } \\
\text { Cc- Pruszków - 26,8 } \\
\text { B - Wrocław - 26,1 } \\
\text { C - Nowy Sącz - 24,9 } \\
\text { Bb - Opole - 24,5 } \\
\end{array}$ & $\begin{array}{l}\text { C - Rzeszów - 26,4 } \\
\text { B - Wejherowo - 26,2 } \\
\text { C - Łomża - 25,8 } \\
\text { C - Stalowa Wola }-25,3 \\
\text { Cc - Białystok }-24,0 \\
\text { C - Nowy Sącz }-23,7 \\
\text { Cc - Przemyś1 }-23,6 \\
\text { Cc - Otwock - 22,8 } \\
\text { C - Krosno - 22,0 } \\
\text { C - Lublin }-21,9\end{array}$ \\
\hline Bronisław Komorowski & Jarosław Kaczyński & Grzegorz Napieralski \\
\hline $\begin{array}{l}\text { B - Sopot - 59,5 } \\
\text { B - Poznań - } 59,4 \\
\text { B - Opole - 58,6 } \\
\text { B - Gdynia - 58,0 } \\
\text { B - Gdańsk - } 57,1 \\
\text { A - Zielona Góra - 55,7 } \\
\text { Aa - Koszalin - } 54,8 \\
\text { B - Chorzów - 54,3 } \\
\text { Bb - Kędzierzyn-Koźle - 54,2 } \\
\text { A - Piła - 54,0 }\end{array}$ & $\begin{array}{l}\text { D - Bełchatów - 51,8 } \\
\text { C - Nowy Sącz - 46,9 } \\
\text { C - Łomża - 46,8 } \\
\text { C - Mielec - 45,4 } \\
\text { C - Stalowa Wola - 45,4 } \\
\text { D - Jastrzębie }-44,6 \\
\text { Cc- Ostrołęka - 44,5 } \\
\text { C - Radom - 44,4 } \\
\text { Cc - Siedlce - 43,8 } \\
\text { Cc - Zamość }-43,0\end{array}$ & $\begin{array}{l}\text { Aa - Zawiercie - 23,3 } \\
\text { A - Będzin - 22,4 } \\
\text { Aa - Sosnowiec - 22,2 } \\
\text { D - Ostrowiec Św. - 22,0 } \\
\text { Aa - Dąbrowa Górnicza - 21,9 } \\
\text { A - Inowrocław - 21,3 } \\
\text { Dd - Konin - 20,4 } \\
\text { Aa - Włocławek - 19,7 } \\
\text { D - Radomsko - 18,9 } \\
\text { D - Głogów - } 18,9\end{array}$ \\
\hline
\end{tabular}

Rok 2010 nie przyniósł żadnych podobnych wątpliwości, choć warto zwrócić uwagę, że najwyższy odsetek poparcia Jarosław Kaczyński odnotował nie w tradycyjnie uznawanych za ,prawicowe” (w niniejszej typologii prawicowe 
i nieliberalne) miastach, takich jak Łomża czy Nowy Sącz, ale w Bełchatowie. Niezmiernie interesujące byłoby zatem bardziej szczegółowe opisanie cech miast z grupy D, tłumaczące skłonność ich mieszkańców do udzielania wysokiego poparcia SLD, a potem PiS.

Dane zaprezentowane w tabeli 10 pozwalają poddać podobnej weryfikacji wyniki wyborów sejmowych 1997 i 2007 roku. Wynik AWS pokazuje zasadność wyjaśnienia dotyczącego wysokiego wyniku Mariana Krzaklewskiego w Wejherowie. Do tego momentu formacje centroprawicowe mogły liczyć na dobre wyniki w miastach grupy prawicowo-liberalnej. Dopiero pęknięcie na osi PO-PiS doprowadziło do reorientacji innych grup wyborców, którzy poparli PiS w miastach takich, jak Bełchatów czy Ostrowiec Świętokrzyski, a PO w miastach takich, jak Inowrocław czy Wałbrzych. Ciekawa jest także lista miast z wysokim poparciem dla UW. Warto dodać, że wysoki poziom poparcia w miastach śląskich (Katowice, Chorzów, Mysłowice, Świętochłowice) można wyjaśnić także tym, iż w okręgu tym kandydował wówczas lider partii Leszek Balcerowicz.

Tabela 10. Miasta, w których odnotowano najwyższy odsetek poparcia dla list $(1997,2007)$

\begin{tabular}{|c|c|c|}
\hline AWS & SLD & UW \\
\hline $\begin{array}{l}\text { B - Wejherowo - 59,0 } \\
\text { C - Nowy Sącz - 50,7 } \\
\text { Bb - Piekary Śląskie - 50,6 } \\
\text { B - Gdańsk - 49,0 } \\
\text { B - Tczew - 48,5 } \\
\text { B - Gdynia - 47,9 } \\
\text { Cc - Tarnów - 47,7 } \\
\text { C - Rzeszów - 47,5 } \\
\text { C - Łomża - 46,6 } \\
\text { C - Stalowa Wola - 46,1 }\end{array}$ & $\begin{array}{l}\text { A - Inowrocław - 53,3 } \\
\text { D - Ostrowiec - 53,0 } \\
\text { Aa - Zawiercie - 52,6 } \\
\text { A - Będzin - 51,0 } \\
\text { Aa - Sosnowiec - 50,8 } \\
\text { Aa - Dąbrowa Górnicza - 50,1 } \\
\text { A - Wałbrzych - 47,2 } \\
\text { Aa -Włocławek - 44,9 } \\
\text { A - Grudziądz - 44,6 } \\
\text { A - Piła - 42,8 }\end{array}$ & $\begin{array}{l}\text { B - Katowice }-27,8 \\
\text { Bb - Gliwice - 25,6 } \\
\text { B - Kraków - 25,6 } \\
\text { B - Wrocław - 24,4 } \\
\text { A - Leszno - 24,3 } \\
\text { B - Opole - 24,1 } \\
\text { B - Chorzów - 23,3 } \\
\text { B - Poznań - 23,2 } \\
\text { E - Mysłowice - 23,2 } \\
\text { Bb - Świętochłowice - 23,1 }\end{array}$ \\
\hline PO & PiS & $\mathrm{LiD}$ \\
\hline $\begin{array}{l}\text { B - Sopot - 61,5 } \\
\text { B - Poznań - 59,7 } \\
\text { B - Gdańsk - 59,7 } \\
\text { B - Opole - 58,5 } \\
\text { B - Gdynia - 58,5 } \\
\text { B - Racibórz - 58,3 } \\
\text { B - Wrocław }-58,2 \\
\text { B - Chorzów - 56,7 } \\
\text { B - Wejherowo - 55,0 } \\
\text { A - Leszno - 54,0 }\end{array}$ & $\begin{array}{l}\text { D - Bełchatów - 45,4 } \\
\text { Cc - Ostrołęka - 43,4 } \\
\text { C - Nowy Sącz - 42,9 } \\
\text { Bb - Piekary Śląskie - 42,7 } \\
\text { C - Stalowa Wola - 41,9 } \\
\text { C - Łomża - 41,9 } \\
\text { C - Radom - 40,7 } \\
\text { D - Jastrzębie Zdrój - 40,5 } \\
\text { D - Mielec - 40,3 } \\
\text { Cc - Zamość - 39,4 }\end{array}$ & $\begin{array}{l}\text { Aa - Gniezno - 26,1 } \\
\text { Aa - Sosnowiec - 24,7 } \\
\text { A - Inowrocław }-23,9 \\
\text { Aa - Zawiercie }-23,8 \\
\text { A - Grudziądz }-23,8 \\
\text { Aa - Włocławek - 23,2 } \\
\text { A - Świnoujście }-22,3 \\
\text { D - Głogów - 22,2 } \\
\text { A - Będzin - 22,0 } \\
\text { Aa - Kalisz - 21,4 }\end{array}$ \\
\hline
\end{tabular}


Rok 2007 przyniósł daleko idące uporządkowanie zachowań wyborczych mieszkańców miast, eliminując jakiekolwiek odstępstwa od reguł. Warto skomentować jedynie pojawienie się wśród najlepszych wyników PiS, w mających cechy podobne do grupy miast prawicowo-liberalnych Piekarach Śląskich. Da się to wyjaśnić tym, że z pierwszego miejsca tej listy kandydował wówczas były wiceprezydent tego miasta i popularny poseł z list AWS, a potem PiS, Jerzy Polaczek, na którego głosy oddało 37,7\% wyborców z Piekar. W wyborach w roku 2011 władze partii przeniosły go do okręgu nr 29 (Gliwice).

\section{Prezydenci miast $\mathrm{i}$ ich afiliacje polityczne}

Jedną z przyczyn, dla których większość badań politologicznych unika - poniekąd słusznie - podsumowania wyników rywalizacji w wyborach prezydentów i burmistrzów miast, jest trudność z ustaleniem ich afiliacji politycznej. Po pierwsze dlatego, że nawet prezydenci będący członkami partii politycznych ukrywają tę przynależność w kampanii wyborczej. Po drugie dlatego, że często korzystają ze wsparcia jednej lub więcej partii, wyrażającego się nie tylko w formie oficjalnego uznania kandydata za własnego, ale np. w niewystawieniu konkurenta.

Temat został podjęty w kilku interesujących tekstach ${ }^{17}$, zgodnie sceptycznych w kwestii traktowania prezydentów ukrywających rzeczywiste afiliacje pod nazwą bezpartyjnego i lokalnego komitetu. Maciej Drzonek proponuje interesujące kategorie kwalifikujące kandydatów na urząd prezydenta miasta - aktorów partyjnych, o łatwej do ustalenia afiliacji, aktorów pozapartyjnych (lokalnych i społecznych) oraz aktorów niby-bezpartyjnych ${ }^{18}$. Z punktu widzenia niniejszego tekstu wyłonienie tych dwóch pierwszych grup nie nastręcza trudności. W przypadku prezydentów należących do grupy trzeciej bardzo łatwo o niekonsekwencję i błąd. O kryteriach, jakie przyjmujemy w uznaniu prezydentów niby-bezpartyjnych za związanych z partią decyduje przy tym w znacznym stopniu kontekst badawczy. Gdybyśmy chcieli ocenić wpływ partii na prezydenta, warto byłoby badać nie tylko formalne członkostwo, ale np. to, czy wystawił on konkurencyjny wobec własnej partii komitet w wyborach do Rady Miasta lub czy przyjął kandydatów partyjnych na listę takiego komitetu.

17 A. Gędźwiłł, Dlaczego sukces?, w: Studia nad wyborami. Polska 2005-2006, red. J. Raciborski, Warszawa 2008; J. Flis, Partie polityczne w wyborach prezydentów miast, „Studia Politologiczne" 2011, vol. 20.

18 M. Drzonek, Reelekcje prezydentów miast w wyborach bezpośrednich w Polsce, Kraków 2013, s. 133-153. 
Niniejszy tekst nie bada jednak tego zagadnienia. Interesuje nas podobieństwo wyników wyborów ogólnopolskich na poziomie badanych miast i wyników wyborów prezydentów miast. Ukryta afiliacja nie jest zatem jedynym problemem, który będziemy musieli rozstrzygnąć. Przyjmiemy regułę, że w sytuacji, gdy przynajmniej raz afiliacja prezydenta była znana wyborcom, jak np. w przypadku wybranego w 2001 roku z list SLD-UP posła Tadeusza Ferenca, który w 2002 roku został prezydentem Rzeszowa, uznajemy, że jako kandydat w późniejszych wyborach powinien być identyfikowany jako związany z lewicą. Podobnie w przypadku prezydentów, którzy byli wybrani z poparciem PO, a następnie zerwali z tą partią, rywalizując z jej kandydatami w kolejnych wyborach. Uznamy ich za kandydatów „,iberalnych lub dawniej z PO”. Podobnie w przypadku innej, dającej się zidentyfikować, grupy prezydentów, którzy w latach 90. XX wieku związani byli z AWS lub partiami centroprawicy (np. prezydent Częstochowy Tadeusz Wrona). Uznamy ich za grupę prezydentów „centroprawicowych" bez afiliacji partyjnej. Grupę tę powiększymy o prezydentów związanych ,dawniej z PiS”.

Jak zatem zakwalifikować kandydata, który startował w 2002 roku z poparciem SLD-UP, a w 2014 roku kandydował z poparciem lewicy i Platformy Obywatelskiej jako niezależny (Tadeusz Ferenc, Rzeszów)? Jak ocenić sytuację, gdy w jednym mieście startują dwaj kandydaci będący członkami PO (Jelenia Góra 2014 r.)? Wreszcie, jaką przynależność przypisać prezydentom, którzy nie mają w swoim życiorysie faktów upoważniających do przypisania ich nie tylko do partii politycznej, ale do którejś ze stron politycznych konfliktów minionego ćwierćwiecza. Najpoważniejszy błąd, jaki można popełnić w takim badaniu, polega na „naciąganiu danych”, tak by afiliację określić w możliwie największej liczbie przypadków. Dlatego też część osób sprawujących urząd prezydenta wyłączyłem z dalszego badania opisując ich jako afiliację „trudną do określenia”, co oznacza trudną do przezwyciężenia niemożliwość połączenia ich aktywności z jakąkolwiek partią lub grupą partii w Polsce.

Jednocześnie oprócz grup kandydatów partyjnych - kandydujących z jasną deklaracją przynależności do partii lub jako kandydaci wysunięci przez jej komitet wyborczy - wskazałem kilka dodatkowych grup. Po pierwsze - grupy prezydentów, którzy zerwali z partią, której poparciem pierwotnie się cieszyli (dawniej PO; dawniej PiS; dawniej SLD); po drugie - grupy prezydentów z wyraźną afiliacją ideową, liberalną - nabytą poprzez członkostwo w UD, UW lub KLD, centroprawicową - za sprawą członkostwa w AWS lub partiach tworzących tę koalicję oraz lewicową, polegającą na związkach z SLD. Nie oznaczyłem 
jako lewicowych prezydentów związanych z obozem władzy w czasach PRL, takich jak Jacek Krywult (Bielsko-Biała) w sytuacji, gdy nie istniały jakiekolwiek związki z lewicą okresu Trzeciej Rzeczpospolitej.

Aby nie operować na małych obejmujących kilka zdarzeń grupach, połączyłem w tabelach 11-15 następujące grupy prezydentów: związanych dawniej z PO z tymi, którzy mają wyraźną afiliację liberalną; związanych dawniej z PiS z tymi, którzy mają wyraźną afiliację cetroprawicową oraz kandydatów z SLD z tymi, którzy ukryli później tę afiliację, zerwali z partią bądź, będąc zawsze kandydatami bezpartyjnymi, mieli wyraźną afiliację lewicową. Prezydentów popieranych przez PSL dołączyłem do grupy o afiliacji trudnej do określenia.

W tabeli 11 zaprezentowano 428 zdarzeń, polegających na wynikach czterech tur wyborów $\left(2002,2006,2010\right.$ i 2014) w 107 miastach $^{19}$. W nawiasach umieściłem liczbę zdarzeń dotyczących miast reprezentujących wyraźne cechy danej grupy. Ponieważ miast należących do grupy A jest 32, to łączna liczba badanych zdarzeń wyborczych w tej grupie wynosi 128, a dla 15 miast o wyraźnych dla tej grupy cechach - 60. W przypadku każdej z grup zaznaczyłem w tabeli najczęstsze zdarzenia.

Tabela 11. Wygrane prezydentów w poszczególnych grupach miast w wyborach lat 2002-2014

\begin{tabular}{|l|c|c|c|c|c|}
\hline \multicolumn{1}{|c|}{ Afiliacja } & A & B & C & D & E \\
\hline PO & $36(20)$ & $33(20)$ & $8(4)$ & $8(5)$ & 5 \\
\hline Dawniej PO, liberalna & $7(1)$ & $22(14)$ & $0(0)$ & $3(1)$ & 0 \\
\hline PiS & $2(2)$ & $1(1)$ & $19(9)$ & $16(6)$ & 3 \\
\hline Dawniej PiS, centroprawicowa & $26(13)$ & $12(8)$ & $20(4)$ & $24(13)$ & 8 \\
\hline SLD, dawniej SLD lub lewicowa & $43(17)$ & $12(5)$ & $8(8)$ & $18(4)$ & 7 \\
\hline Inna, trudna do określenia & $14(7)$ & $20(4)$ & $17(7)$ & $15(7)$ & 21 \\
\hline Razem & $128(60)$ & $100(52)$ & $72(32)$ & $84(36)$ & 44 \\
\hline
\end{tabular}

Pozwala to na stwierdzenie, że wskazania dotyczące prezydentów miast wykazują pewną zbieżność z ustalonymi na podstawie wyników wyborów, ale daleką od automatycznego poparcia dla kandydatów dominujących w danym mieście opcji. Dokładniejszej uwagi wymagać będzie przede wszystkim 26 przypadków zwycięstw kandydatów centroprawicowych w miastach lewicowo-liberalnych

19 W przypadku Zielonej Góry wziąłem pod uwagę wynik wyborów ze stycznia 2015 r., przeniesionych z jesieni $2014 \mathrm{r}$. 
i 12 przypadków sukcesów kandydatów lewicy w miastach prawicowo-liberalnych.

Warto zwrócić jednak uwagę, że 14 z 26 sukcesów centroprawicowych kandydatów w miastach lewicowo-liberalnych to czterokrotny wybór prezydentów Bolesławca (Piotr Roman, dwa pierwsze zdarzenia przypisano PiS), Inowrocławia (Ryszard Brejza), Jaworzna (Paweł Silbert) i Stargardu (Sławomir Pajor). Osiem dalszych to zwycięstwa z roku 2002, a 4 kolejne to ponowne elekcje zwycięzców z 2002 roku. Można zatem uznać, że sukcesy wszystkich centroprawicowych prezydentów w miastach lewicowo-liberalnych mają swe źródło w zwycięstwach z 2002 roku. Co więcej, spośród 11 zwycięzców z 2002 roku trzech sprawowało urząd prezydenta wcześniej, dwóch było posłami na Sejm III kadencji, a dwóch dalszych starostami okolicznych powiatów.

W podobny sposób można wyjaśnić 12 przypadków sukcesu kandydatów lewicy w prawicowo-liberalnych miastach. Osiem z nich to czterokrotne zwycięstwa Jacka Majchrowskiego w Krakowie i Michała Zaleskiego w Toruniu. Trzy kolejne przypadki to zwycięstwa kandydatów SLD-UP, w najlepszym dla lewicy 2002 roku, odniesione w Bytomiu, Kędzierzynie-Koźlu i Raciborzu. Dwunasty to reelekcja Wiesława Fąfary - prezydenta Kędzierzyna. Tylko w 2002 roku kandydaci lewicy zdobywali po raz pierwszy władzę w miastach grupy B, później nie wygrali w żadnym z tych miast, o ile nie walczyli - jak Majchrowski i Zaleski - z pozycji urzędującego prezydenta.

Tabela 12. Wygrane prezydentów w poszczególnych grupach miast w wyborach 2002 roku

\begin{tabular}{|l|c|c|c|c|c|}
\hline \multicolumn{1}{|c|}{ Afiliacja } & A & B & C & D & E \\
\hline PO & $3(2)$ & $5(4)$ & $0(0)$ & $2(1)$ & 1 \\
\hline Dawniej PO, liberalna & $1(0)$ & $5(3)$ & $0(0)$ & $1(0)$ & 0 \\
\hline PiS & $1(1)$ & $1(1)$ & $3(2)$ & $2(0)$ & 1 \\
\hline Dawniej PiS, centroprawicowa & $11(5)$ & $3(2)$ & $7(1)$ & $6(4)$ & 4 \\
\hline SLD lub lewicowa & $13(6)$ & $5(2)$ & $3(3)$ & $6(2)$ & 2 \\
\hline Inna, trudna do określenia & $3(1)$ & $6(1)$ & $5(2)$ & $4(2)$ & 3 \\
\hline Razem & $32(15)$ & $25(13)$ & $18(8)$ & $21(9)$ & 11 \\
\hline
\end{tabular}

Przyjrzyjmy się jeszcze wynikom w poszczególnych latach. Rok 2002 (tab. 12) przyniósł - jak już stwierdziłem - największą liczbę wyników, w których zachodzi rozbieżność między preferencjami mieszkańców miast w wyborach 
ogólnopolskich a afiliacjami wybranych prezydentów. Warto zwrócić uwagę na dużą liczbę centroprawicowych zwycięzców wyborów w miastach grupy A oraz 9 zwycięstw lewicy w miastach grupy B i C (m.in. w Krakowie, Rzeszowie, Nowym Sączu). Warto jednak pamiętać, że wybory te odbywały się, gdy PO i PiS nie miały jeszcze rozbudowanych struktur partyjnych, w wielu mniejszych miastach silną pozycję zachowały środowiska AWS-owskie, a jednocześnie SLD był u szczytu władzy.

W wyborach w 2006 roku mieliśmy do czynienia z sytuacją odmienną. Koalicja zawarta przez PiS z Samoobroną i LPR osłabiła pozycję tej partii w dużych miastach, ale pozwoliła jej na osiem zwycięstw w mniejszych miastach grupy $\mathrm{D}$, tam gdzie głównym rywalem PiS była lewica lub kandydaci niezależni. Wyraźnie zaznacza się wzrost pozycji PO w miastach grupy A i B, a dotknięta głębokim kryzysem SLD zdołał utrzymać swoją pozycję jedynie w grupie A. W tych wyborach zresztą wielu kandydatów tej formacji ujętych w naszych zestawieniach jako „lewica” porzuciło SLD-owski szyld kryjąc się często pod nazwami komitetów lokalnych.

Tabela 13. Wygrane prezydentów w poszczególnych grupach miast w wyborach w 2006 roku

\begin{tabular}{|l|c|c|c|c|c|}
\hline \multicolumn{1}{|c|}{ Afiliacja } & A & B & C & D & E \\
\hline PO & $9(6)$ & $8(6)$ & $2(1)$ & $1(2)$ & 2 \\
\hline Dawniej PO, liberalna & $1(0)$ & $5(3)$ & $0(0)$ & $1(0)$ & 0 \\
\hline PiS & $1(1)$ & $0(0)$ & $5(2)$ & $8(2)$ & 0 \\
\hline Dawniej PiS, centroprawicowa & $6(2)$ & $3(2)$ & $5(2)$ & $6(4)$ & 2 \\
\hline SLD lub lewicowa & $12(4)$ & $3(1)$ & $1(1)$ & $4(1)$ & 2 \\
\hline Inna, trudna do określenia & $3(2)$ & $6(1)$ & $5(2)$ & $1(0)$ & 5 \\
\hline Razem & $32(15)$ & $25(13)$ & $18(8)$ & $21(9)$ & 11 \\
\hline
\end{tabular}

Wybory w roku 2010 przebiegały w warunkach silnej polaryzacji między PO a PiS, jednak partia Jarosława Kaczyńskiego bardzo wysoko je przegrała straciła władzę we wszystkich sejmikach, a zachowała tylko w ośmiu miastach. W obu dużych partiach doszło do politycznej emancypacji prezydentów miast, którzy często zrywali więzi z partią i konkurowali - zwykle udanie - z jej kandydatami. W przypadku PO proces ten był bezpieczny w miastach grupy A i B - w pozostałych kategoriach ,,bezpartyjny liberalny” lub ,dawny polityk PO” nie istniał wcale. 
Tabela 14. Wygrane prezydentów w poszczególnych grupach miast w wyborach w 2010 roku

\begin{tabular}{|l|c|c|c|c|c|}
\hline \multicolumn{1}{|c|}{ Afiliacja } & A & B & C & D & E \\
\hline PO & $11(6)$ & $9(5)$ & $2(1)$ & $3(2)$ & 1 \\
\hline Dawniej PO, liberalna & $1(0)$ & $6(4)$ & $0(0)$ & $0(0)$ & 0 \\
\hline PiS & $0(0)$ & $0(0)$ & $4(2)$ & $4(2)$ & 0 \\
\hline Dawniej PiS, centroprawicowa & $5(3)$ & $3(2)$ & $5(1)$ & $7(3)$ & 1 \\
\hline SLD lub lewicowa & $11(4)$ & $2(1)$ & $2(2)$ & $4(1)$ & 2 \\
\hline Inna, trudna do określenia & $4(2)$ & $5(1)$ & $5(2)$ & $3(1)$ & 7 \\
\hline Razem & $32(15)$ & $25(13)$ & $18(8)$ & $21(9)$ & 11 \\
\hline
\end{tabular}

Rok 2014 przyniósł wiele ciekawych procesów - w tym dalsze wzmocnienie pozycji PO w miastach grup A i B oraz PiS w miastach grupy C. Może to prowadzić do wniosku, że w warunkach rezygnacji z walki o reelekcję, kończącej kadencję prezydenta, łatwiej zdobyć ten fotel kandydatom z dominującej w wyborach parlamentarnych partii niż tym bez wyraźnej afiliacji.

Tabela 15. Wygrane prezydentów w poszczególnych grupach miast w wyborach w 2014 roku

\begin{tabular}{|l|c|c|c|c|c|}
\hline \multicolumn{1}{|c|}{ Afiliacja } & A & B & C & D & E \\
\hline PO & $13(6)$ & $11(5)$ & $4(2)$ & $2(0)$ & 1 \\
\hline Dawniej PO, liberalna & $4(1)$ & $6(4)$ & $0(0)$ & $1(1)$ & 0 \\
\hline PiS & $0(0)$ & $0(0)$ & $7(3)$ & $2(2)$ & 2 \\
\hline Dawniej PiS, centroprawicowa & $4(3)$ & $3(2)$ & $3(0)$ & $5(2)$ & 1 \\
\hline SLD lub lewicowa & $7(3)$ & $2(1)$ & $2(2)$ & $4(0)$ & 1 \\
\hline Inna, trudna do określenia & $4(2)$ & $3(1)$ & $2(1)$ & $7(4)$ & 6 \\
\hline Razem & $32(15)$ & $25(13)$ & $18(9)$ & $21(9)$ & 11 \\
\hline
\end{tabular}

\section{Podsumowanie i wnioski}

O zbieżnych wynikach wyborów ogólnopolskich i lokalnych możemy mówić, gdy prezydent w miastach lewicowo-liberalnych należy do PO lub SLD lub też jest zbliżony do tych partii. W przypadku miast prawicowo-liberalnych - gdy należy do PO, prawicowych i nieliberalnych - do PiS, zaś do lewicowych i nieliberalnych, gdy należy do PiS, SLD lub PSL. 
O ewidentnych rozbieżnościach możemy mówić, gdy prezydent z PiS lub centroprawicy rządzi miastem należącym do grupy lewicowo-liberalnej, a w przypadku prezydenta z silną afiliacją PiS - także do prawicowo-liberalnej. Inny przykład ewidentnych rozbieżności to rządy prezydenta z SLD lub szerzej pojętej lewicy w dwóch grupach miast prawicowych - zarówno liberalnych, jak i nieliberalnych. Trzecia grupa rozbieżności to rządy prezydentów z PO w miastach nieliberalnych (lewicowych i prawicowych) oraz rządy prezydentów zbliżonych do PO lub liberalnych w miastach lewicowych i nieliberalnych.

Przypadków takich rozbieżności odnotowaliśmy łącznie 46 przy liczbie badanych wynoszącej 428 (czterokrotne wybory w 107 miastach prezydenckich). Można też uznać za rozbieżne wyniki obejmujące wszystkie zwycięstwa prezydentów z PO lub liberalnych w miastach nieliberalnych (dalszych 11 przypadków) oraz prezydentów lewicowych w miastach prawicowych i nieliberalnych (8 przypadków) oraz zwycięstwa PiS w miastach prawicowo-liberalnych (jeden przypadek). Kwestią do dyskusji jest to, czy za rozbieżne uznać zwycięstwa centroprawicowców spoza PiS w ośrodkach należących do tej ostatniej grupy, zwłaszcza w sytuacji, gdy obserwowaliśmy bardzo dobre wyniki AWS w miastach tej grupy.

Możemy zatem uznać, że przypadki rozbieżne stanowią niewiele ponad 15\% wyników w całej próbie, przypadki neutralne - kiedy prezydentem zostaje kandydat niezależny lub należący do PSL, czyli partii, która odgrywa w rywalizacji parlamentarnej w miastach rolę marginalną - kolejne 20\%, a nieco mniej niż 65 to przypadki zbieżne z pozycją miasta w opisanym wyżej czterobiegunowym układzie. Co więcej, musimy pamiętać, że najwięcej „rozbieżnych” wyników przypadło na rok 2002, a zatem pierwsze powszechne wybory prezydentów miast. W wyborach tych silną pozycję mieli reprezentanci ,bezpartyjnej centroprawicy”, sukcesorzy AWS oraz zwycięskiej lewicy spod znaku SLD. Dominujące dziś na scenie politycznej partie PO i PiS dopiero budowały swoje struktury.

W niektórych miastach, jak np. w Nowym Sączu, doszło do dużego rozproszenia głosów centroprawicy (na czworo kandydatów centroprawicy padło 61\% głosów w pierwszej turze, na kandydatkę solidarnościowego centrum - dalsze 13\%), dzięki czemu do drugiej tury przeszedł kandydat SLD-UP, zdobywając zaledwie 17\% głosów, jednak to on w drugiej turze pokonał Andrzeja Czerwińskiego z PO. Niechęć części prawicowych wyborców do byłego prezydenta miasta była na tyle silna, że wynik Czerwińskiego wzrósł z 8,6 tys. w pierwszym głosowaniu do jedynie 10,1 tys. w drugiej turze. Jego kontrkandydat - Józef A. Wiktor powiększył swój elektorat z 5,0 tys. w pierwszym głosowaniu do 11,9 tys. w drugim. 
Podobnie rzecz się miała w Krakowie, gdzie - jak wszystko wskazuje - wyborcy PiS i PO woleli dalsze rządy J. Majchrowskiego niż zwycięstwo kandydata antagonistycznej, choć programowo bliższej, partii.

Zaprezentowane zestawienie wyników wyborów ogólnopolskich z wynikami bezpośrednich wyborów prezydentów miast pozwala na sformułowanie kilku podstawowych wniosków:

a) zachowania wyborcze w obu typach elekcji nie są tożsame, ale ujawnione różnice mają najczęściej swe źródło w rozstrzygnięciach z roku 2002 i ich późniejszych konsekwencjach; wybory w 2002 roku były eksperymentem dla lokalnych elit politycznych, które w wielu wypadkach nie potrafiły przewidzieć zachowań wyborców; przebiegały też w warunkach instytucjonalnej przebudowy sceny partyjnej - rozpadu AWS i UW, tworzenia struktur PiS i PO;

b) obserwowana w latach 2002-2014 generalna tendencja do reelekcji urzędującego prezydenta wzmacnia efekt różnicy w tych miastach, w których prezydent o odmiennej od dominującej w mieście afiliacji został wybrany w 2002 roku;

c) znaczącą grupą pozostają prezydenci bezpartyjni o trudnej do wskazania afiliacji ideowo-politycznej; w ich przypadku decydujące znaczenie mogłoby mieć studium o relacjach między prezydentem a większością w radzie miasta, wymagające jednak dobrej znajomości lokalnych relacji; zapewne na podstawie tych danych, a także informacji o ich rywalach, możliwe będzie ustalenie efektywnej afiliacji „rywalizacyjnej” (poparcie dla prezydenta jako zablokowanie perspektywy rządów PO, PiS lub SLD w mieście);

d) granicą efektywności dokonywanych pomiarów powinna być świadomość, że personalny charakter wyborów osłabia partyjny wymiar rywalizacji a siła kandydatów sprawujących urząd prezydenta jest tak samo ważnym czynnikiem analizy co afiliacja polityczna ich rywali.

Interesujące byłoby przy tym pogłębienie niniejszego badania o obserwację relacji między przeprowadzanym równolegle głosowaniem w wyborach sejmikowych oraz w wyborach prezydentów miast na najniższym dostępnym poziomie - obwodów wyborczych - oraz analiza wzorów rywalizacji w pierwszej i drugiej turze wyborów. Być może wypracowany na podstawie tych danych model pozwoliłby wyeliminować to, co uznajemy zwykle za „zbieg okoliczności” wpływający na wybór tego, a nie innego prezydenta oraz przypisać „rywalizacyjną” afiliację przynajmniej części prezydentów niezależnych. 


\section{Bibliografia}

Bartkowski Jerzy, Tradycja i polityka. Wpływ tradycji kulturowych polskich regionów na współczesne zachowania społeczne i polityczne, Wydawnictwo Akademickie Żak, Warszawa 2003.

Drzonek Maciej, Reelekcje prezydentów miast $w$ wyborach bezpośrednich $w$ Polsce, Wydawnictwo Dante, Kraków 2013.

Flis Jarosław, Galicyjskie odmienności wyborcze, w: Szkoły polskiej demokracji, red. Artur Wołek, Ośrodek Myśli Politycznej, Kraków 2014.

Flis Jarosław, Partie polityczne w wyborach prezydentów miast, „Studia Politologiczne” 2011, vol. 20.

Flis Jarosław, Złudzenia wyboru. Społeczne wyobrażenia i instytucjonalne ramy $w$ wyborach do Sejmu i Senatu, Wydawnictwo Uniwersytetu Jagiellońskiego, Kraków 2014.

Gędźwiłł Adam, Dlaczego sukces?, w: Studia nad wyborami. Polska 2005-2006, red. Jacek Raciborski, Wydawnictwo Scholar, Warszawa 2008.

Główny Urząd Statystyczny, Powierzchnia i ludność Polski w przekroju terytorialnym w 2014 r., Warszawa 2015.

Grabowska Mirosława, Boskie i cesarskie. Religijność oraz stosunki między państwem a Kościołem a zachowania polityczne, w: Wybory parlamentarne 1997. System partyjny, postawy polityczne, zachowania wyborcze, red. Radosław Markowski, ISP PAN - Fundacja im. Friedricha Eberta, Warszawa 1999.

Grabowska Mirosława, Podział postkomunistyczny. Społeczne podstawy polityki w Polsce po 1989 roku, Wydawnictwo Scholar, Warszawa 2004.

Jasiewicz Krzysztof, Portfel czy różaniec? Ekonomiczne i aksjologiczne determinanty zachowań wyborczych, w: Wybory parlamentarne 1997. System partyjny, postawy polityczne, zachowania wyborcze, red. Radosław Markowski, ISP PAN - Fundacja im. Friedricha Eberta, Warszawa 1999.

Kabath Elżbieta, Rykiel Zbigniew, Metody badań geografii wyborczej $i$ ich wyniki, w: Problemy interpretacji wyników metod badawczych stosowanych $w$ geografii spoleczno-ekonomicznej i gospodarce przestrzennej, red. Henryk Rogacki, Wydawnictwo Naukowe Bogucki, Poznań 2003.

Kowalski Mariusz, Polaryzacja zachowań wyborczych jako rezultat cywilizacyjnego rozdarcia kraju, w: Przestrzeń wyborcza Polski, red. Mariusz Kowalski, Polskie Towarzystwo Geograficzne - Oddział Akademicki, Warszawa 2013.

Kyloušek Jakub, Pink Michal, Šedo Jakub, Volební mapa města Brna, Centrum pro studium demokracie a kultury, Brno 2007. 
Lewis Paul G., Political parties in Post-Communist Eastern Europe, Routledge, LondonNew York 2000.

Lisowski Andrzej, Zróżnicowanie społeczne i zachowania wyborcze w wybranych miastach w Polsce, „Prace i Studia Geograficzne” 2009, t. 42.

Matyja Rafał, Rywalizacja polityczna w Polsce, Ośrodek Myśli Politycznej, Kraków 2013.

Sobczyński Marek, Zróżnicowanie przestrzenne postaw politycznych mieszkańców Łodzi, Wydawnictwo Uniwersytetu Łódzkiego, Łódź 2000.

Szawiel Tadeusz, Podziat lewica-prawica $w$ polityce oraz $w$ szerszym kontekście kulturowym, w: Mirosława Grabowska, Tadeusz Szawiel, Budowanie demokracji. Podziały społeczne, partie polityczne i społeczeństwo obywatelskie w postkomunistycznej Polsce, Wydawnictwo Naukowe PWN, Warszawa 2001.

Węcławowicz Grzegorz, Jarosz Andrzej, Śleszyński Przemysław, Atlas Warszawy, z. 5, Wybory parlamentarne 1991 i 1993, IGiPZ PAN, Warszawa 1998.

\section{Streszczenie}

Celem niniejszego artykułu jest ocena związku między profilami elektoratów miast prezydenckich, ustalonymi na podstawie ogólnopolskich wyborów prezydenckich i sejmowych, a afiliacjami politycznymi prezydentów miast. Na podstawie danych z sześciu elekcji - trzech prezydenckich $(1995,2005,2015)$ i trzech sejmowych $(1991,2001$, 2011) - dokonano podziału miast na grupy, charakteryzujące się podobnymi preferencjami wyborców. Następnie zbadano zależność między trwałymi cechami zachowań w wyborach ogólnopolskich a wynikami wyborów prezydentów miast. Badanie zamyka próba wyjaśnienia prawidłowości i odstępstw dostrzeżonych w zachowaniach wyborców 107 badanych ośrodków.

Słowa kluczowe: zachowania wyborcze, miasta polskie, prezydenci miast, wybory samorządowe, wybory parlamentarne, wybory prezydenckie 


\title{
VOTING BEHAVIOR IN CITIES 1990-2015 AND POLITICAL AFFILIATIONS OF CITY PRESIDENTS AFTER 2002
}

\begin{abstract}
Summary
The goal of this article is to evaluate the relationship between the profiles of main polish cities, established on the basis of nationwide presidential and parliamentary elections, and the political affiliations of City Presidents (Mayors). Based on data from six elections: three presidential ones $(1995,2005,2015)$ and three parliamentary ones $(1991$, 2001, 2011), cities were divided into groups characterized by similar voter preferences. Then, the relationship between the permanent characteristics of behaviour in national elections and the results of City President elections was examined. The survey was concluded with an attempt to explain the regularities and the deviations observed in the behavior of voters in 107 surveyed centers.
\end{abstract}

Keywords: electoral behavior, Polish cities, the mayors of towns, local elections, parliamentary elections, presidential elections 